\title{
A new addition to the alien flora of Tunisia, Amaranthus spinosus L. (Amaranthaceae s.1.), with notes on $A$. diacanthus Raf.
}

\author{
Duilio Iamonico $^{1 \star}$, Ridha El Mokni ${ }^{2,3}$ \\ ${ }^{1}$ University of Rome Sapienza, Department PDTA, Section Environment and Landscape, via Flaminia 72, \\ 00196 Rome, Italy \\ ${ }^{2}$ Laboratory of Botany and Plant Ecology, Faculty of Sciences of Bizerta, University of Carthage, Jarzouna-7021, \\ Bizerta, Tunisia \\ ${ }^{3}$ Faculty of Pharmacy of Monastir, University of Monastir, BP. No 207, Avenue Avicenna, Monastir-5000, Tunisia
}

\begin{abstract}
Amaranthus spinosus L. (Amaranthaceae s.1.), a species native to the Neotropics, has been found in four localities (Bizerta, Bir Bouregba, Hammamet, and Nabeul) of N. Tunisia. Our discovery represents the first record at national level, and the second one for N. Africa. Morphological characters and ecological data are given. Nomenclatural notes are provided for the name A. diacanthus, which was regarded by some authors as heterotypic synonym of A. spinosus. A neotype is designated in the present paper based on a specimen preserved at LSU.
\end{abstract}

Keywords: alien species, Amaranthus, neophyte, typification

\section{Introduction}

The genus Amaranthus L. (Amaranthaceae Juss.) comprises about 70 mostly annual, monoecious and dioecious species, of which approximately 40 are native in America (see e.g., Costea et al. 2001, Iamonico 2015a). Some species of Amaranthus are used as ornamentals and are able to escape from cultivation, having an economic impact mainly on agricultural systems (reduction of productivity and crop quality), while other taxa have an ecological impact on native flora and vegetation [e.g. A. tuberculatus (Moq.) J.D.Sauer in a riparian habitat] (see e.g., Iamonico 2015b). The infrageneric classification of Amaranthus still remains unresolved, lacking a comprehensive molecular study (see e.g., Hernández-Ledesma et al. 2015). On the basis of morphology and chorology, Mosyakin and Robertson (1996) recognized three subgenera: subg. Acnida (L.) Aellen ex K.R. Robertson with three sections, subg. Albersia (Kunth) Gren. et Godr. with four sections, and subg. Amaranthus, with three sections and two subsections. According to Mosyakin and Robertson (1996: 278), Amaranthus spinosus L. is the only species belonging to Amaranthus subg. Amaranthus sect. Centrusa Griseb.

The Flora of Africa (see SANBI 2012 and literature therein, Iamonico 2015c and literature therein) currently includes
Amaranthus spinosus, which is recorded in many countries of central and southern parts of the continent, while in the north it occurs only in Egypt. As part of an ongoing nomenclatural and taxonomic study on the genus Amaranthus (see e.g., Iamonico 2014a, 2014b, 2015a, 2015c, 2016a, 2016b, 2016c, Iamonico and Das 2014) and the Tunisian Amaranthaceae s. lat. (see e.g., Iamonico and El Mokni 2017, Sukhorukov et al. 2016), some populations have been found that certainly refer to A. spinosus. The number of Tunisian Amaranthus species has thereby been increased, since this finding represents the first record for the Flora of Tunisia and the second for the Flora of N. Africa. Moreover, the name Amaranthus diacanthus, which some authors suggest be regarded as a synonym of A. spinosus (e.g., Rojas-Sandoval 2015, Wunderlin et al. 2017), is here investigated from the nomenclatural point of view, as it is still untypified.

\section{Materials and methods}

The work is based on an extensive analysis of literature, and examination of the specimens kept in the Herbaria FI, HFLA, LINN, LSU, and RO (acronyms according to Thiers 2019+), and in the Herbarium of the Faculty of Pharmacy of

* Corresponding author, e-mail: d.iamonico@yahoo.it 
Monastir and of the Faculty of Sciences of Bizerta (not listed in Index Herbariorum), where the personal collections of R. El Mokni are kept.

The articles cited through the text agree with the Shenzen Code, ICN (Turland et al. 2018).

\section{Results and discussion}

\section{Nomenclatural notes on Amaranthus diacanthus}

Rafinesque (1817: 31-32) described A. diacanthus and provided a short diagnosis. Rafinesque (l.c.) also cited the Flore Louisinaise by Robin (1807). The latter author (Robin 1807: 372) listed an Atriplex taxon, but he did not report any epithet. As a consequence, Rafinesque (l.c.), probably on the basis of the detailed description made by Robin (l.c.), proposed the plants occurring in Louisiana (S-USA) as a new species. We have not been able to trace Rafinesque's material, which could be useful for typification purposes. We looked at material collected by C. C. Robin in Louisiana, which could be observed and used by C. S. Rafinesque, to describe A. diacanthus. Unfortunately, no Robin specimen was traced [moreover, Stafleu and Cowan (1985: 812) reported "Herbarium and Types: Unknown"]. Since no original material seems to be extant, no lectotype can be designed, and neotypification is required (see Arts. 9.2, 9.3, and 9.7). Accordingly, we selected a specimen preserved at LSU (catalog number 83081) and collected in Louisiana, in Webster County. The LSU-83081 is here designated as the neotype of the name Amaranthus diacanthus.

Concerning the identity of $A$. diacanthus, note that the diagnosis by Rafinesque (1817) and the description of Atriplex sp. made by Robin (1807) include an important morphological character [“...glomerulis bispinosis..." by Rafinesque (1807), and "...les paques de fleurs des sisselles accompagnés de deux épines divergentes...” by Robin (1807)]: the occurrence of a spine-like feature at the bases of the floral glomerules [according to Costea and Tardif (2003) these structures are actually the bracts of the first flower in the first cyme of the glomerule which metamorphoses in the early phase of the onthogeny]. This structure was the basis for the selection of the neotype, representing a unique feature in the genus Amaranthus, characterizing the species currently known as A. spinosus (see e.g., Bojian et al. 2003, Mosyakin and Robertson 2003, Iamonico 2015a). As a consequence, these two names can be treated as heterotypic synonyms, the Linnaean having nomenclatural priority (1753 vs. 1817).

\section{Taxonomic treatment}

Amaranthus spinosus L., Sp. Pl., 2: 991. 1753.

Lectotype (designated by Fawcett and Redle 1914: 103): Herb. Linnaeus, no. 1117.27 (LINN!). Image of the lectotype available at http://linnean-online.org/11653/).

= Amaranthus diacanthus Raf., Fl. Ludov.: 31-32. 1817.

Neotype (here designated): U.S.A., Louisiana, Webster County, Camp Minden, $1.2 \mathrm{~km}$ E of Jim Davis Cemetery,
0.3 km NW of Richardson Cemetery, 14 July 2003, L. Blay, T. Pazzaglia et N. Hastings 906 (LSU-83081!). Image of the neotype available at http://data.cyberfloralouisiana.com/lsu/).

Description - Herbs 6-15 dm tall, monoecious, annual (therophyte). Stems erect, glabrous brownish, branched. Leaves green to reddish (on the upper surface), ovate to lanceolate, rhomboidal [(2.0-)2.5-6.5(-7.5) × (1.0-)2.5-4.0(-3.5) $\mathrm{cm}$ ], with entire margins, apex obtuse or acute, mucronate, base cuneate, glabrous, petioled (petiole $1.5-8.5 \mathrm{~cm}$ long), associated to 2 spine-like structures (modified bracts), 7.0$8.0 \mathrm{~mm}$ long. Synflorescences terminal, panicle-like, the main florescence up to $15 \mathrm{~cm}$ long, usually green and axillary glomerules. Floral bracts lanceolate $(3.0-4.0 \times 0.5-1.0 \mathrm{~mm})$ as long as or shorter than the perianth, acute, awned, margin entire, glabrous. Staminate flowers with 5 tepals, ovatelanceolate; stamens 5. Pistillate flowers with 5 tepals, lanceolate-spathulate $(3.5-4.0 \times 0.9-1.0 \mathrm{~mm})$, with usually obtuse and mucronate apex; stigmas $3-4$. Fruit brown or yellowish, ellipsoidal $(2.0-2.1 \times 1.4-1.5 \mathrm{~mm})$ as long as or slightly shorter than the perianth, smooth below, rugose on top, dehiscent. Seed lenticular (about $0.9 \mathrm{~mm}$ in diameter), brown.

Phenology - Flowering and fruiting time October-December.

Habitat - Roadsides, public gardens, and cultivated areas with trees (e.g. Citrus sp.), at 6-41 m a.s.l.

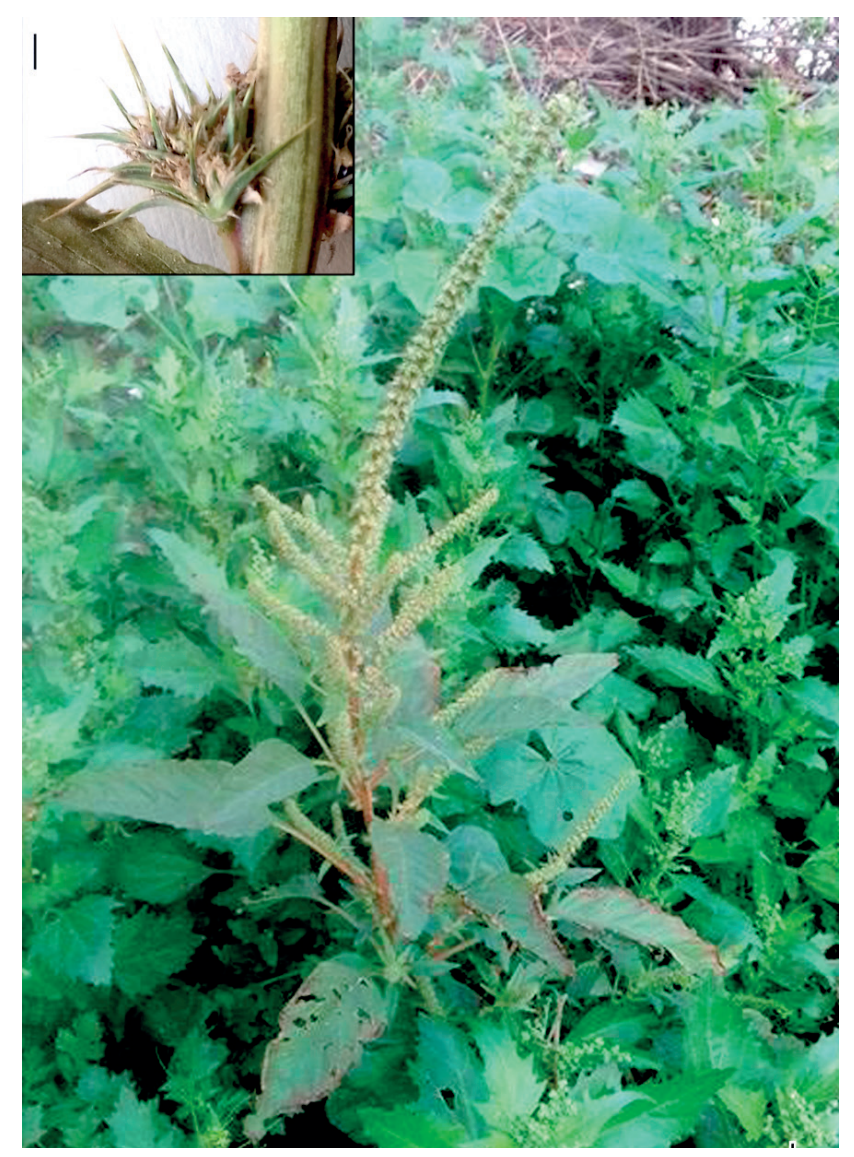

Fig. 1. Habit of Amaranthus spinosus L. (bar $=1 \mathrm{~cm}$ ) at Nabeul region in Tunisia with detail of spine-like structures (left corner; bar $=4 \mathrm{~mm})$ (photos by R. El Mokni). 
Distribution in Tunisia - Four populations (16-18 individuals in total) were found in the following localities: Bizerta [three individuals (each about $150 \mathrm{~cm}$ tall) covering an area of $9 \mathrm{~m}^{2}$ ], Bir Bouregba [two individuals (each about $70 \mathrm{~cm}$ tall) covering $2 \mathrm{~m}^{2}$ ], Hammamet [three-four individuals (each about $90 \mathrm{~cm}$ tall covering $4 \mathrm{~m}^{2}$ ], and $\mathrm{Na}$ beul [eight-nine individuals (each about $60 \mathrm{~cm}$ tall) covering $25 \mathrm{~m}^{2}$ ].

Native range and status of naturalization in Tunisia $-A$. spinosus is a neophyte species native to the Neotropics, while it is an alien in many countries of Europe (Iamonico 2015c), C. and S. Africa (Sanbi 2012), N. and E. Australia (Atlas Living of Australia 2016), and Asia (see e.g., Townsend 1974, Bojian et al. 2003). Concerning N. Africa, this species was previously recorded only in Egypt (see Boulos 2009: 56, Iamonico 2015c).

The four populations of $A$. spinosus discovered in Tunisia (see above "Distribution in Tunisia") were observed from 2012 to 2016. Although the plants seem to self-replace without direct human intervention, we prefer to consider $A$. spinosus as casual alien species in Tunisia at the moment.

\section{References}

Atlas of living Australia 2016+: Amaranthus spinosus L. Retrived March 15, 2017 from [http://bie.ala.org.au/species/http:// id.biodiversity.org.au/node/apni/2886429].

Bojian, B., Clemants, S. E., Borsch, T., 2003: Amaranthus L. In: Wu, Z. Y., Raven P. H., Hong, D. Y. (eds.), Flora of China 5, 415-429. Science Press, Beijing and Missouri Botanical Garden Press, St. Louis.

Boulos, L., 2009: Flora of Egypt Checklist. Revised annotated edition. Al-Hadara, Cairo.

Costea, M., Tardif, F. J. 2003: The bracteoles in Amaranthus (Amaranthaceae): their morphology, structure, function and taxonomic significance. Sida 20, 969-985.

Costea, M., Sanders, A., Waines, G., 2001: Preliminary results towards a revision of the Amaranthus hybridus complex (Amaranthaceae). Sida 19, 931-974.

Fawcett, W., Rendle, A. B., 1914: Flora of Jamaica containing description of the flowering plants known from the island 3 . British Museum, London.

Greizerstein, E., Poggio, L. 1992: Estudios citogeneticos en seis hibridos del genero Amaranthus. Darwiniana 31, 159-165.

Hernández-Ledesma, P., Berendsohn, W.G., Borsch, T., Mering, S. von, Akhani, H., Arias, S., Castaneda-Noa, I., Eggli, U., Eriksson, R., Flores-Olvera, H., Fuentes-Bazan S., Kadereit, G., Klak, C., Korotkova, N., Nyffeler, R., Ocampo, G., Ochoterena, H., Oxelman, B., Rabeler, R., Sanchez, A., Schlumpberger, B., Uotila, P. 2015: A taxonomic backbone for the global synthesis of species diversity in the angiosperm order Caryophyllales. Willdenowia 45, 281-383.

Iamonico, D., 2010: Biology, life-strategy and invasiveness of Amaranthus retroflexus L. (Amaranthaceae) in central Italy: preliminary remarks. Botanica Serbica 34, 137-145.

Iamonico, D. 2013. Amaranthus tuberculatus (Moq.) J.D.Sauer invasive species compendium. Wallingford, UK: CAB International. Retrieved April 13, 2017 from http://www.cabi.org/ isc/datasheet/112200.

Iamonico, D., 2014a: Amarathus gangeticus (Amaranthaceae), a name incertae sedis. Phytotaxa 162, 299-300.
Chromosome number - A. spinosus is a diploid species with $2 \mathrm{n}=34$ (see e.g., Greizerstein and Poggio 1992, Song et al. 2002, Sheidai and Mohammadzdeh 2008).

Specimina visa - Tunisia: Bizerta (North-Bizerta, Corniche), 37019'31" N, 0951'52" E, uncultivated land, $06 \mathrm{~m}$ a.s.l., 27 October 2013, R. El Mokni (HFLA, Herb. Univ. Bizerta); Nabeul (North-Nabeul, Cap-Bon), 36 $26^{\prime} 26^{\prime \prime} \mathrm{N}$, $10^{\circ} 42^{\prime} 25^{\prime \prime} \mathrm{E}$, roadsides, $08 \mathrm{~m}$ a.s.l., 09 December 2015, R. El Mokni (Herb. Univ. Monastir); Nabeul (North-Hammamet, Cap-Bon), 36² $24^{\prime} 35^{\prime \prime} \mathrm{N}, 10^{\circ} 36^{\prime} 06^{\prime \prime} \mathrm{E}$, cultivated land, 22 m a.s.l., 10 December 2016, R. El Mokni (Herb. Univ. Monastir); Nabeul (Bir Bouregba, Cap-Bon), 36²5’39" N, 10³4'56" E, roadsides, $41 \mathrm{~m}$ a.s.l., 09 December 2015, R. El Mokni (Herb. Univ. Monastir).

\section{Acknowledgements}

Thanks to the Directors and Curators of all quoted official herbaria and colleagues who own the cited personal herbaria for their support during our visits, loan of specimens, photographs or for providing interesting information.

Iamonico, D., 2014b: Lectotypification of Linnaean names in the genus Amaranthus L. (Amaranthaceae). Taxon 63, 146-150.

Iamonico, D., 2015a: Taxonomic revision of the genus Amaranthus (Amaranthaceae) in Italy. Phytotaxa 199, 1-84.

Iamonico, D., 2015b: Amaranthus tuberculatus (Moq.) J.D.Sauer: Invasive Species Compendium. Wallingford, UK: CAB International. Retrieved March 15, 2017 from http://www.cabi.org/ isc/datasheet/112200.

Iamonico, D., 2015c: Amaranthaceae Juss. In: Euro+Med Plantbase - the information resource for Euro-Mediterranean plant diversity. Retrieved January 3, 2017 from http://ww2.bgbm. org/EuroPlusMed/PTaxonDetail.asp?NameCache=Amarant hus\&PTRefFk=7300000.

Iamonico, D., 2016a: Nomenclature survey of the genus Amaranthus (Amaranthaceae). 3. Names linked to the Italian flora. Plant Biosystems 150, 519-531.

Iamonico, D., 2016b: Nomenclature survey of the genus Amaranthus (Amaranthaceae). 4. The intricate questions around the name Amaranthus gracilis. Botanica Serbica 40, 61-68.

Iamonico D., 2016c: Nomenclature survey of the genus Amaranthus (Amaranthaceae). 5. Moquin-Tandon's names. Phytotaxa $273,81-114$.

Iamonico, D., Das, S., 2014: Amaranthus bengalense (Amaranthaceae) a new species from India, with taxonomical notes on $A$. blitum aggregate. Phytotaxa 181, 293-300.

Iamonico, D., El Mokni, R., 2017: Amaranthus palmeri, a second record for the African flora and notes on A. sonoriensis nom. nov. Bothalia 47, a2100.

Mosyakin, S. L., Robertson, K. R., 1996: New infrageneric taxa and combinations in Amaranthus (Amaranthaceae). Annales Botanici Fennici 33, 275-281.

Mosyakin, S. L., Robertson, K. R. 2003: Amaranthus L. In: Flora of North America Editorial Committee (eds.), Flora of North America North of Mexico (Magnoliophyta: Caryophyllidae) 4, 410-435. Oxford University Press, Oxford.

Rafinesque, C. S. 1817: Florula Ludoviciana; or a flora of the State of Louisiana. C. Wiley \& Co., New York. 
Robin, C. C. 1807: Voyages dans l'intérieur de la Louisiane: de la Floride occidentale, et dans les isles de la Martinique et de Sanit-Domingue pedant les années 1802, 1803, 1804, 1805 et 1806. C. Wiley \& Co., New York.

Rojas-Sandoval, J. 2015. Amaranthus spinosus L. - invasive species compendium. Wallingford, UK: CAB International. Retrieved April 13, 2017 from http://www.cabi.org/isc/datasheet/4653.

Sanbi, 2012: Amaranthus spinosus L. In: National assessment: Red List of South African plants version 2014.1. Retrieved January 3, 2017 from http://www.ville-ge.ch/musinfo/bd/cjb/africa/ details.php?langue $=$ an\&id $=318$.

Sheidai, M., Mohammadzdeh, Z. 2008: Cytogenetic study of Amaranthus L. species in Iran. Cytologia 73, 1-7.

Song, B.-H., Zhang, X.-J., Li, F.-Z., Wan, P. 2002: Chromosome numbers of 14 species in Amaranthus from China. Acta Phytotaxonomica Sinica 40, 428-432.

Stafleu, A. F., Cowan, R. S. 1985: Taxonomic Literature, 2nd ed., 5 (Sal-Ste). Scheltema \& Holtema, Utrecht \& Bohn.

Sukhorukov, A. P., Martín-Bravo, S., Verloove, F., Maroyi, A., Iamonico, D., Catarino, L., El Mokni, R., Daniel, T. F., Belyaeva,
I. V., Kushunina, M., 2016: Chorological and taxonomic notes on African plants. Botany Letters 163, 417-428.

Thiers, B., 2019+: Index Herbariorum: A global directory of public herbaria and associated staff. New York Botanical Garden's Virtual Herbarium. Retrieved January 3, 2017 from http:// sweetgum.nybg.org/ih/.

Townsend, C. C. 1974: Amaranthaceae Juss. In: Nasir, E., Ali, S. I. (eds.), Flora of West Pakistan 71, 1-49. Ferozsons Press, Rawalpindi.

Turland, N. J., Wiersema, J. H., Barrie, F. R., Greuter, W., Hawksworth, D. L., Herendeen, P. S., Knapp, S., Kusber, W.-H., Li, D.-Z., Marhold, K., May, T. W., McNeill, J., Monro, A. M., Prado, J., Price, M .J., Smith, G. F. (eds.) 2018: International Code of Nomenclature for algae, fungi, and plants (Shenzhen Code) adopted by the Nineteenth International Botanical Congress, Shenzhen, China, July 2017. Regnum Vegetabile 159. Koeltz Botanical Books, Glashütten, Germany.

Wunderlin, R. P., Hansen B. F., Franck A. R., Essig, F. B. 2017. Atlas of Florida Plants. Retrieved April 13, 2017 from http://florida. plantatlas.usf.edu/ Plant.aspx?id=1453. 